\title{
CCL5 wt Allele
}

National Cancer Institute

\section{Source}

National Cancer Institute. CCL5 wt Allele. NCI Thesaurus. Code C49749.

Human CCL5 wild-type allele is located within 17q11.2-q12 and is approximately $36 \mathrm{~kb}$ in length. This allele, which encodes C-C motif chemokine 5 protein, plays a role in immune cell chemotaxis and histamine release. 